IRA-International Journal of Management \& Social Sciences

ISSN 2455-2267; Vol.05, Issue 01 (2016)

Pg. no. 104-121

Institute of Research Advances

http://research-advances.org/index.php/RAJMSS

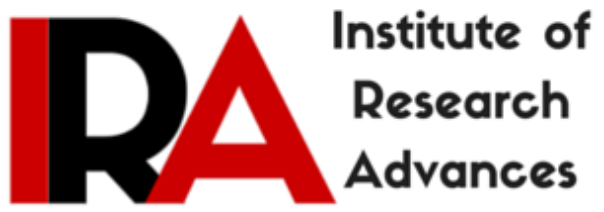

\title{
Impact of BREXIT Referendum on Indian Stock Market
}

\author{
${ }^{1}$ Dr. S. Sathyanarayana \\ Associate Professor, \\ MP Birla Institute of Management, \\ Bangalore, India.

\section{${ }^{2}$ Prof. Sudhindra Gargesha Joint director, MP Birla Institute of Management, India.}

Type of Review: Peer Reviewed.

DOI: http://dx.doi.org/10.21013/jmss.v5.n1.p12

\section{How to cite this paper:}

Sathyanarayana, S., \& Gargesha, S. (2016). Impact of BREXIT Referendum on Indian Stock Market. IRA-International Journal of Management \& Social Sciences (ISSN 24552267), 5(1), 104-121. doi:http://dx.doi.org/10.21013/jmss.v5.n1.p12

(C) Institute of Research Advances

(cc) EY-NC

This work is licensed under a Creative Commons Attribution-Non Commercial 4.0 International License subject to proper citation to the publication source of the work.

Disclaimer: The scholarly papers as reviewed and published by the Institute of Research Advances (IRA) are the views and opinions of their respective authors and are not the views or opinions of the IRA. The IRA disclaims of any harm or loss caused due to the published content to any party. 


\section{ABSTRACT}

Immediately after World War II, many European nations felt it was important to unite the European nations to form a union for the economic and social benefits. However, the dream of a "Common European Union" is still quite far from reality. The EU is the England's largest business partner. Almost fifty percent of Britain's trade is with the EU. Now, Britain's decision to leave the EU is a death blow to the EU. Today, the Brexit is viewed as the next big financial event since 2008 subprime crisis causing dent on the global economy. History has exhibited that stock market plays a major role in any economy. Stock markets have been impacted by various macro and micro economic factors. Therefore, the main objective of this empirical paper is to investigate the pricing behaviour of the chosen benchmark indices (Sensex and Nifty) with respect to a major political event (Brexit referendum) and its implications for regulators, researchers and market participants. For the purpose of the study the data has been collected from 24-06-2015 to 19-07-2016 and the collected data has been tested for stationarity by applying ADF test. The event study methodology has been employed to determine the impact of Brexit referendum on India stock market. In order to capture the historical volatility the standard deviation of the abnormal returns of the selected indices has been computed. GARCH $(1,1)$ model have been employed to ascertain the existence of ARCH/GARCH effect in the indices. We found a significant impact of Brexit referendum on both the chosen indices on the event day. Nobody knows the actual impact of the Brexit on the world economy in the long run. The bulk of studies on Brexit referendum have concluded that the impact on the Britain's economy would be significant and adverse. However, the shock on the European Union would be smaller, although no extensive macroeconomic assessment has been published.
\end{abstract}

Key words: Brexit, Efficient Market Hypothesis, GARCH $(1,1)$, The European Union, macroeconomic variables

\title{
I. INTRODUCTION
}

The concept of efficient market was proposed by Eugene Fama (1970), describes that the prices of securities reflect all the available macro and micro economic information. Therefore, the historical prices lose the predictive power to forecast the future prices. Consequently, prices of assets cannot be predicted by the participants as the assets prices move randomly and restrict them from earning the abnormal returns. The EMH concept has been studied since its inception by both the practioners and the academicians. The concept of event study methodology was first pioneered by James Dolley (1933) who used this method to investigate the returns pattern on stock split announcement. Later, Archie Bakay (1948) and John Ashley (1962) used the event study methodology. Today, the event study methodology is one of the most applied analytical tool in finical literature and has emerged as a very important statistical technique for analysing the impact of corporate actions such as stock split, earnings announcement, bonus shares etc. and major economic events such as budget proposal, general elections, oil shocks, terrorist attack, etc. on the security prices.

The concept of EMH has been investigated in numerous studies over the years for various extreme economic and sensational events such as general elections (Kithinji and Ngugi (2013); Person, (2012); Jones (2002); Zuwena Zainabu (2014); Maning (1989); Peel and Pope (1993); Santa-Clara and Valkanov (2003); Bialkowski, et al., (2008); Anderson et al., (2008); Hensel and Ziemba (1995); Vuchelen (2003)), terrorist attacks and its impact on stock market (Aslam and Kong (2011); Suleman (2012); Akysha and Shakil (2005)) including September 9/11 attacks (Carter and Simkins (2004)), unfavourable political news (Mei and Guo, (2002) Lin and Wang, (2005); Swary (1986)), favorable political news (Kongprajya, (2010)), special events like Tiananmen Accident on stock market (Ma, Sun and Tang (2003)), resignation of a president (Ahmad (2009)), the crash of the space shuttle Challenger (Maloney and Mulherein (2003)), impact of hurricane on stock market (Angbazo (1996)). Sabnavis (2005) tried to investigate the political disturbance on Sensex. The impact of natural disasters/catastrophes on stock returns has also been investigated by researchers for example, Shelor et al. (1990), Californian earthquake disaster on US stock market (Andrew, Valadkhani and Worthington (2004)), Wan (2011) natural disasters in Japan; Javid (2007) on earthquake in Pakistan. 
Few empirical studies tried to investigate the impact of Union budget on stock market for example, Gupta and Kundu (2006); Kaur (2004), Divya et al. (2015); Rao (1997); Thomas and Shah (2002); Kutchu (2012); Babu and Venkateswara (2013); Soni Anil (2009). Apart from this couple of studies have proved that security prices are also effected by interest rate announcement (Kim (2003); Rehman and Raoof, (2010); Chakradhara (2008)); Ho and Saunders (1981); Rigobon and Sack, (2004); Fleming and Remolona, (1999)). Similarly other macro-economic variables including inflation, money supply and its impact on stock prices for example treasury yield Cook and Hahn (1989); Hamilton (2008). There has been a large number of empirical studies tried to investigate the relationship between the oil prices and stock market returns. For example Kilian (2008); Ciner (2001), Hamilton (2003); Kavussanos and Marcoulis (1997); Manning (1991); Hamilton and Herrera (2004); Sadorsky (1999). Mohanty (2004) tried to investigate the impact of various policy issues and its impact on stock market. Kim and Nguyen (2008); Gasbarro and Monroe (2004), Bernanke and Kuttner (2005) tried to investigate the impact of monetary policy announcements on stock market. The bank rate on commercial paper rates (Jayadev and Sunil kumar (2001), impacts of crude prices on exchange rates (e.g., Coudert et al., (2008); Chen and Chen (2007)), exchange rate and stock price (Joseph (2002); Branson (1983); Dimitrova (2005); Doong et al (2005)), FIIs inflow and stock returns (Babu and Prabheesh (2007)), inflation and stock markets (Fama (1981); Asprem (1989); Mukhopadhyay and Sarkar (2003), Few more studies tried to investigate the impact of special events on stock market, for example, global financial crisis (Rafaqet Ali and Muhammad Afzal (2012)), Islamic holy month on the stock market (Hussain (1998)), currency devaluation (Aggarwal, 1981), political risk (Bittlingmayer (1998); Beaulieu, et al. (2005)) etc. Majority of these studies documented that most of the macro economic variables and political events influence the movement of stock markets. Moreover, the stock markets are highly sensitive to both national and international events and react spontaneously after their occurrence. Volatility in security prices during such macroeconomic and political events is an opportunity for testing the validity of the efficient market hypothesis. Abrupt political events like Breixt can put more pressure on the stock market and the way it functions.

In the current study we have taken an important event after the subprime crisis 2008, which shook the global stock markets. Stock markets across the globe lost about $\$ 2$ trillion in value on $24^{\text {th }}$ Friday, 2016 when final verdict went against the EU. The DAX (Germany) index, fell 7 percent, the IBEX (Spanish) Index was down by 11 percent. FTSE (London bench mark index) 100 has fallen 8.7 percent and the FTSE 250 index (mid-size companies) dropped by 12 percent (this is the most reliable reflection of the British economy). CAC 40 (France) index fell by 8.6 percent. Nikkei (Japanese) 225 index was down 8 percent. US stock market recorded a drop of more than 3 percent. The Dow Jones industrial average dropped by 655 points (the ninth largest one day crash recorded in the history of the Dow Jones). Nasdaq dropped by 4.12 percent (the largest drop since 2011). On the same day Indian stock market too crashed as England opted for leaving the EU. The Sensex dropped by 604.51 points and Nifty Fifty 181.85 points. Consequently, Indian investors lost Rs. two lakh crore in wealth. Among the prominent Asian indices, Hang Seng index tumbled down by 4.67 percent, Kospi (Korean index) tumbled by 3.1 percent and Australia's benchmark ASX 200 Index sank 3.2 percent. The pound fell to $\$ 1.37$ against the US dollar and witnessed an eight percent drop. The stock market perceived this one has a negative news for the U.K in the near term at least. All the money withdrawn from the stock market was poured into traditional safe assets like gold, Japanese yen and government bonds. There are considerable levels of uncertainty about what would happen if England leaves the EU. Moreover, the market participants and regulators expect stock market to react to such political events. Yet, they may lack the competency to measure properly the vigour and the direction of the reaction. Therefore, the referendum would have a very robust economic implication for market participants especially from the context of the EU. A stock market's briskness to incorporate state-of-the-art information into prices is often referred to informational efficiency. Therefore, an impartial stock market is one in which security prices unbiased estimation of fundamental values of financial assets. Now a days, the legitimacy of market efficiency is challenged by the behavioural finance literature. Therefore, the main aim of this research paper is to investigate the pricing behaviour of the chosen 
Indian stock Indices (Sensex and Nifty Fifty) with reference to a major political event (Brexit referendum) and its implications for regulators, researchers and market participants.

\section{LITERATURE REVIEW}

The random-walk theory presumes that stock price is uncorrelated with historical prices. It assumes that there is no trend is visible in stock price movements and they are independent. Therefore, the EMH theory suggests that historical prices have no predictive capacity over the future prices. Thus, subsequent price shift should be random (Alexander (1961); Fama, (1965); Jensen and Benington, (1970) and Fama, (1970) Malkiel (1995); Elton et al. (1993), Chopra et al. (1992); Seppi (1992); DeBondt and Thaler (1985); Charest (1978)). The event study methodology is one of the most used tool in economics, accounting and financial research. The first event study documented in the financial literature was by James Dolley (1933), cited in MacKinley (1997) in his article Event Studies in Economics and Finance. John Dolley tried to explore how share prices react to stock splits announcement and found that there was an impact to the extent of 60 percent. Later many researchers have employed this methodology for example John H. Myers and Archie Bakay (1948), John Ashley (1962); MacKinlay (1997); Kothari and Warner (2006). But, what event study methodology are we following today was outlined by Ball \& Brown (1968) and Fama et al. (1969). In simple words, event study methodology examines the behaviour of corporates' stock and bond prices (returns) around specific events. Later, the concept of the EMH has been tested in numerous studies over the years. According to Robin and Jessica (2014) an event is an informational announcement of any kind which occurrence is assumed to be unexpected by the market. In financial literature majority of the empirical studies tried to investigate the impact of an event on the stock returns (abnormal returns), however, several other studies tried to explore trading volume and even volatility of the returns when certain event occurs. According to EMH the market is said to be efficient, if the stock prices react quickly and efficiently to the new information or event without any bias. Therefore, the abnormal returns signal the market reaction to the unforeseen event.

Stock market attitude during general elections was examined by researchers, for example Bialkowski et al. (2008); Zach (2003); Nicholas Chen (2004); Pantzalis et al. (2000); Beaulieu et al. (2005); Liu (2007); Khalid, Ahmed et al. (2010); Gartner (1994); Gartner et al. (1995); Acemoglu, et al. (2003); Dopke and Pierdzioch (2006); Stovall (1992); Anoop Singh (2006); Kim and Mei (1999); Beyer et al. (2008); Nordhaus, (1975); Li and Born (2006); MacRae, (1977); Ploeg (1984); Bernanke and Kuttner (2005); Cowart (1978), Hibbs (1977), Allvine, O’Neill (1980); Drazen (2001) and Sturm (2013); Johnson et al. (1999) and Zhao et al. (2004). However, Nordhaus (1975) created the first political business cycle. In this pioneering study he deliberated the various issues like the political decisions pertaining to the current or future welfare. In an empirical study by Bittlingmayer (1992) documented that political confusion or uncertainty affects the stock market. Similar view was held by Schwert (1989). In a study by Tzachi Zach (2003) documented that returns on the TASE following political actions are more intense than returns on days that do not follow political actions. In an empirical study Zach (2003) documented that the stock market is highly volatile on event day as compared to ordinary trading days in Tel Aviv Stock market. In an investigation by Goodell and Vähämaa (2013) documented that the US election process generates uncertainty in stock market, similar view was documented by Ortega and Tornero (2009). In an empirical study by Zuwena Zainabu (2014) with an intention to understand the effect of the general elections on the return of the stock market in Kenya concluded that investors should carefully plan and carry out investments during and after the periods of the general elections as the returns could be affected either positively or negatively during that period. In an empirical study by Diamonte et al. (1996) argued that political risk has a significant impact on developing economies than in developed economies. Similarly Erb et al. (1996) documented that country-risk measures have high degree of correlation with future equity returns. Peel and Pope (1993) explored the stock market's reaction during general elections and they find inefficiency in stock prices around the time of elections. Similar observation was documented by Campello (2007). A study by Booth and Booth (2003) documented that when the ruling party is republican the fixed securities had fetched significantly higher returns, however, under democrats the 
small cap stocks experiences the excess returns. Identical results were documented by Santa-Clara and Valkanov (2003); Huang (1985); Johnson et al. (1999); Pantzalis et al. (2000). However, couple of studies contradicted this view for example Jones and Banning (2000); Abidin et al. (2010) and Dopke and Pierdzoich (2006). In a study by Niederhoffer et al. (1970) concluded that the stock market performances during Republican and Democratic administrations have no systematic difference. Niederhoffer et al. (1971) empirically studied the reaction of the stock market on major world events and found an impact on the S\&P 500 index. Cutler et al. (1989) conducted identical studies by taking major world events and found a dissimilar returns and risk profile between the major events and nonevents days. In a study by Evelita E. Celis and Leow Jia Shen (2015), found that the investors take asymmetric treatments to the election information and the government policy. In the twentieth century, intensive empirical studies of the events like terrorists attack and its impact on stock market became quite popular. For examples empirical studies done by Aslam and Kang (2013); Ramiah and Graham (2013); Marc Chesney et al (2011); Anh Phuong Nguyen and Carl E. Enomoto (2009); and Khakan Najaf et al. (2015) found the evidence. The issue of influence of Brexit referendum and its impact on the stock markets have not available in the literature, therefore the current study has been undertaken to investigate the impact of Brexit referendum on Indian stock markets. The structure of the current empirical study is as follows. Section two provides a brief discussion of various empirical papers from this field. Section three outlines the data sources and the methodology employed for the purpose of the current study. In section four the empirical results are presented and in the last section discussion and conclusion have been made and the results are compared with the possible evidence.

\section{RESEARCH DESIGN}

\section{DATA FOR THE PURPOSE OF THE STUDY}

As the current empirical study was analytical in nature, the data for the purpose of the study was dependent on secondary sources. For the purpose of the study Sensex and Nifty Fifty indices were chosen. For study purpose, the adjusted closing price for both the index namely Sensex and Nifty fifty have been collected from capitalline data base. Daily returns are calculated as logarithmic differences of daily closing prices.

\section{OBJECTIVES OF THE STUDY}

The current has been undertaken with the following objectives.

1. To examine the reaction of Indian benchmark indices (Sensex and Nifty) to Brexit referendum.

2. To examine whether there is any abnormal returns around the event date.

3. To investigate the Indian stock markets reaction reflect the market efficiency in semi strong form or not.

\section{HYPOTHESIS OF THE STUDY}

H0: There is no significance difference between the mean returns before the event (Brexit) and the after the (Brexit) event. $\left(\mu_{1}=\mu_{2}\right)$

H1: There is a significance difference between the mean returns before the event (Brexit) and the after the (Brexit) event. $\left(\mu_{1} \neq \mu_{2}\right)$

\section{PLAN OF ANALYSIS}

To investigate the impact of Brexit referendum on Indian stock market (Sensex and Nifty) the event study methodology has been employed. For the purpose of the study the data has been collected from 24-06-2015 to 19-07-2016 from capitalline data base. The first event study documented in the financial literature was by James Dolley (1933). Thereafter, Masulis (1980), DeAngelo and Rice 
(1983) have utilised this methodology to investigate the impact of macro and micro economic variables on the stock markets. For the purpose of the study we have used the same methodology to investigate the impact of Brexit referendum on various selected stock indices. The dates on which the Brexit referendum came out were taken as the event date $(t=0)$. The thirty one days enclosing the referendum (i.e., $\mathrm{t}=-15, \ldots . ., 0 \ldots,+15)$ is labelled as the event window. The days before the Brexit referendum event period (i.e., -245...-15) are labelled as the estimation period. The abnormal returns (AR) of the selected indices for the event window were computed. In order to get the flawless results log returns were computed on Sensex and Nifty Fifty indices for the entire study period.

In the first step the expected return for the window period (ER) was estimated by using the Sharpe's (1964) model $\left[\mathrm{R}_{\mathrm{it}}=\alpha+\left(\beta^{*} \mathrm{Rm}_{\mathrm{t}}+\mathrm{e}_{\mathrm{it}}\right)\right]$. In the second phase, the abnormal return (AR) was computed by deducting the Actual returns (AR) by expected returns (ER). In third step, the Cumulative Abnormal Returns (CAR) for the 30 days has been calculated. The CAR has been calculated by adding the daily AR for the entire event window of 30 days. It is generally applied to analyse the adjustment of prices to state-of-the-art information in our study it is the Brexit referendum. In the last phase student $\mathrm{t}$-test to test has been run to investigate the significance difference in the mean returns before and after the Brexit referendum.

\section{SPECIFICATION OF THE MODEL}

\section{$\operatorname{GARCH}(1,1)$}

\section{MEAN EQUATION}

Sensex Returns $=\mathrm{C} 1+\mathrm{C} 2 * \mathrm{CR}+\mathrm{e}---------\rightarrow(1.1)$
Nifty Fifty Returns $=\mathrm{C} 1+\mathrm{C} 2 * \mathrm{CR}+\mathrm{e}--------\rightarrow(1.2)$

Sensex and Nifty Fifty returns - is the dependent variable and FTSE 100 is the independent variable

VARIANCE EQUATION - THIS IS THE GARCH $(1,1)$ MODEL

$\mathrm{H}_{\mathrm{t}}=\mathrm{C} 3+\mathrm{C} 4 \mathrm{H}_{\mathrm{t}-1}+\mathrm{C} 5^{*} \mathrm{e}_{\mathrm{t}-1}^{2}+\mathrm{C} 6{ }^{*} \mathrm{CR}----------\rightarrow(1.2)$

Here, $\mathbf{H}_{\mathbf{t}}=$ variance of the residual (error term) derived from equation 1.1 and 1.2 (current day's variance or volatility of Index return)

\section{DATA ANALYSIS}

In case of Sensex it was observed that the highest Abnormal Return (AR) recorded in the pre-event period ranging from the lowest value of -0.012869276 with a $t$ value of -1.57172299 (statistically not significant)on day -5 to the highest value of 0.01440066 with a t value of 1.75875066 (statistically not significant)on day -6 . However, in the post-event period the highest Abnormal Return (AR) recorded ranging from the lowest value of -0.012429592 on day 3 with a t value of -1.518024403 (statistically not significant) to the highest value of 0.019001654 on day 12 with a $t$ value of 2.320669509 (statistically significant). On the event day i.e. Brexit results announcement day the abnormal return was 0.025392241 with a t value of 3.101151087 (statistically significant). The Sensex results show that in -15 to +15 days event window period, none of the Abnormal Return (AR) were statistically significant at conventional level of 5\% other than day 12 and day 0 the event day. Therefore, we can conclude that Brexit referendum has an impact on Sensex on the event day.

However, in case of Nifty fifty, it was observed that the highest Abnormal Return (AR) recorded in the pre-event period ranging from the lowest value of -0.013942608 on day - 5 with a $t$ value of 1.630472342 (statistically not significant) to the highest value of 0.013206845 with a $t$ value of 1.544430988 (statistically not significant) on day -6 . However, in the post-event period the highest Abnormal Return (AR) recorded ranging from the lowest value of -0.013230584 on day 3 with a $t$ value of -1.547206965 (statistically not significant) to the highest value of 0.017280312 with a t value of 2.020789107 on day 12 (statistically significant). On the event day (0) i.e. Brexit results 
announcement day the abnormal returns were 0.023632173 with a $t$ value of 2.763586544 (statistically significant). The Nifty 50 results show that in -15 to +15 days event window period, none of the Abnormal Return (AR) were statistically significant at conventional level of 5\% other than for day 12 and on the event day (0). Therefore, we can conclude that Brexit referendum has an impact on Nifty Index on day 12 and the event day.

TABLE No. 4.1

T TEST RESULTS: SENSEX

\begin{tabular}{|l|r|r|r|r||}
\hline & \multicolumn{2}{c|}{ Sensex* 15 days } & \multicolumn{2}{c|}{ Sensex** 7 days } \\
\hline \hline & \multicolumn{1}{|c|}{ Variable 1 } & Variable 2 & \multicolumn{1}{c|}{ Variable 1 } & \multicolumn{1}{c|}{ Variable 2 } \\
\hline \hline Mean & -0.000101699 & 0.000095851 & -0.002275309 & -0.002551662 \\
\hline \hline Variance & 0.0000555373 & 0.00007845075 & 0.0000984298 & 0.00008144649 \\
\hline \hline t Stat & -0.066098797 & & 0.05451636 & \\
\hline t Critical two-tail & 2.048407142 & & 2.17881283 & \\
\hline & \multicolumn{2}{|c|}{ Nifty* 15 days } & \multicolumn{1}{c|}{ Nifty ** 7 days } \\
\hline & Variable 1 & Variable 2 & Variable 1 & \multicolumn{1}{c|}{ Variable 2 } \\
\hline Mean & -0.000715662 & 0.0000725491 & -0.00321332 & -0.002877759 \\
\hline Variance & 0.0 .00005460 & 0.000052549 & 0.00009469 & 0.000078715 \\
\hline t Stat & -0.078993372 & & -0.067419551 & \\
\hline \hline t Critical two-tail & 2.048407 & & 2.178813 & \\
\hline \hline
\end{tabular}

In order to ascertain any significant difference between the pre-event window abnormal returns (-15 to -1$)$ and post event window abnormal returns (+15 to 1$)$ for 15 days event window and 7 days event window student $t$ test was run. It is evident from the above the table No. 4.1 that for Sensex as the $t$ value -0.066098797 is less than the t critical two-tail value (2.048407142), we cannot reject the null hypothesis, meaning that there is no significant difference between pre-event window abnormal returns and post event abnormal returns. In case of 7 days event window the $t$ stat is 0.05451636 which is less that the $\mathrm{t}$ critical value two-tail 2.17881283, therefore we cannot reject the null hypothesis. In case for Nifty fifty index for 15 days event window as the t value -0.078993372 is less than the t critical two-tail value (2.048407), we cannot reject the null hypothesis, meaning that there is no significant difference between pre-event window abnormal returns and post event window abnormal returns. In case of 7 days event window the $t$ stat was -0.067419551 which was less that the $\mathrm{t}$ critical two-tail value 2.178813 , therefore we cannot reject the null hypothesis. Therefore we can conclude that, Brexit referendum has an impact on Indian stock market only on the event day and for the fifteen days event window and seven days event window hardly any impact.

GRAPH 4.1

GRAPH SHOWING T STATS

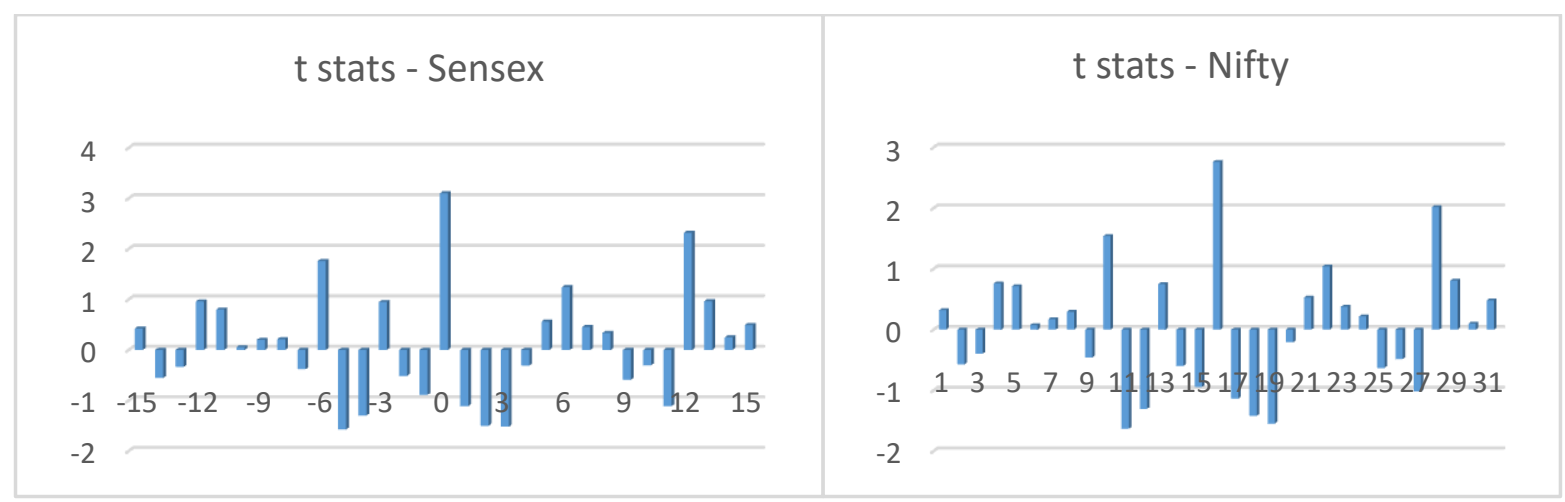


TABLE No. 4.2

TABLE SHOWING CHANGE IN THE HISTORICAL VOLATILITY RETURNS FOR THE EVENT WINDOW

\begin{tabular}{|l||r||l||l||l|l||l|l||}
\hline & \multicolumn{1}{|c|}{ Sensex } & FTSE & Nifty & & \multicolumn{1}{l|}{ Sensex } & \multicolumn{1}{l|}{ FTSE } & \multicolumn{1}{l|}{ Nifty } \\
\hline \hline SD -15 & 0.00745234 & 0.013102 & 0.007389438 & -7 & 0.00992117 & 0.010281 & 0.009731123 \\
\hline \hline SD +15 & 0.008857243 & 0.015573 & 0.008517576 & +7 & 0.009024771 & 0.02125 & 0.008872168 \\
\hline Change & 0.001404903 & 0.002471 & 0.001128138 & & -0.0008964 & 0.010969 & -0.00085895 \\
\hline F & 1.412575791 & & 1.328645764 & & 1.203001993 & & 1.203001993 \\
\hline F Critical & 2.483725741 & & 2.483725741 & & 4.283865714 & & 4.283865714 \\
\hline \hline & Accept & & Accept & & Accept & & Accept \\
\hline
\end{tabular}

This present study employs the historical volatility (standard deviation) and GARCH $(1,1)$ modelling technique to analyse the possible shift in volatility of the chosen indices (Sensex and Nifty fifty). In this case the standard deviation of the abnormal returns is taken as a measure of historical volatility of the both the indices. It is evident from the table No.4.2 that the SD of pre Brexit event of Sensex was 0.00745234 and for post event was 0.008857243 . Therefore in case of Sensex it has increased by 0.001404903 . The F value for Sensex was 1.412575791 which was lesser than the critical value 2.483725741 therefore, we cannot reject the null hypothesis, meaning that there was no significant change in the historical volatility (standard deviation).

In case of Nifty Fifty pre Brexit referendum the SD was 0.007389438 and post Breixt referendum it was 0.008517576 . The historical volatility in Nifty fifty increased by 0.001128138 . The F value for Nifty was 1.328645764 which was lesser than the critical value 2.483725741 therefore, we cannot reject the null hypothesis, meaning that there is no significant change in the historical volatility between pre-event window volatility (standard deviation) and post event volatility (standard deviation) in case of Nifty.

That the SD of pre Brexit event in case of Sensex for 7 days event window was 0.00992117 and for post event was 0.009024771 . Therefore fore in case of Sensex it has come down by -0.0008964 . In case of Nifty Fifty pre Brexit referendum the SD was 0.009731123 and post Breixt referendum it was 0.008872168 . Once again historical volatility in Nifty fifty was come down by -0.00085895 . In either cases we cannot reject the null hypothesis meaning that there is no significant change in the historical volatility between pre-event window volatility (standard deviation) and post event window volatility (standard deviation).

GRAPH 4.2

\section{GRAPH SHOWING STANDARD DEVIATION}

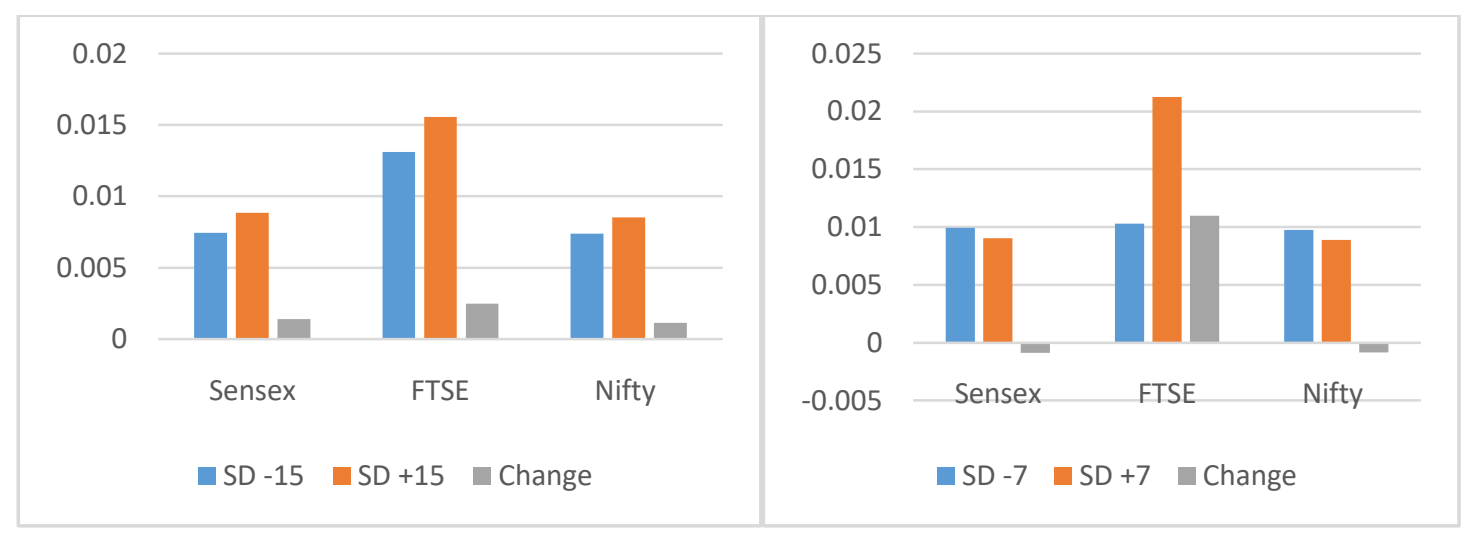

ARCH and GARCH models are commonly used in modelling a time series data that display timevarying volatility clustering (because the current period volatility can be affected by the previous 
period volatility, as volatility is time varying). ARCH-type models are sometimes considered to be in the family of stochastic volatility models, although this is strictly incorrect since at time $t$ the volatility is completely pre-determined (deterministic) given previous values. The basic version of the least squares model assumes that the expected value of all error terms, when squared, is the same at any given point. This assumption is called homoskedasticity, and it is this assumption that is the focus of ARCH/ GARCH models. The review of literature also backing the time varying volatility by applying the ARCH and GARCH techniques (Bomfin, 2003). Therefore in the current study the GARCH model has been used to investigate the time varying volatility of pre-Brexit referendum and post Brexit referendum independently and later results are compared for Pre Brexit referendum and Post Brexit referendum periods.

TABLE No. 4.3

\section{TABLE SHOWING CHANGES IN PERSISTENCE VOLATILITY AROUND PRE-BREXIT AND POST BREXIT REFERENDUM}

\section{SENSEX - PRE BREXIT (PRESENCE OF ARCH /GARCH $(1,1)$ EFFECT)}

\begin{tabular}{|c|c|c|c|c|c|c|c|c|}
\hline & \multicolumn{4}{|c|}{ Before Brexit Referendum } & \multicolumn{4}{|c|}{ After Brexit Referendum } \\
\hline & \multicolumn{2}{|c|}{ (RESID(-1)^2) } & \multicolumn{2}{|c|}{ GARCH(-1) } & \multicolumn{2}{|c|}{ (RESID(-1)^2) } & \multicolumn{2}{|c|}{ GARCH(-1) } \\
\hline & z-Stat & Prob. & z-Stat & Prob. & z-Stat & Prob. & z-Stat & Prob. \\
\hline Sensex (Y) & -0.502430 & 0.6154 & 3.069563 & 0.0021 & -1.567710 & 0.1169 & 1.162880 & 0.2346 \\
\hline Sensex (Y) & -1.015561 & $\begin{array}{l}0.3098 \\
\end{array}$ & 5.046587 & $\begin{array}{l}0.0000 \\
\end{array}$ & -0.809765 & $\begin{array}{c}0.4181 \\
\end{array}$ & 1.162843 & 0.2449 \\
\hline $\begin{array}{l}\text { Sensex }(Y) \\
\end{array}$ & -1.645204 & $\begin{array}{l}0.0999 \\
\end{array}$ & $\overline{c 7.505718}$ & 20.0000 & -1.597032 & $\begin{array}{c}0.1103 \\
\end{array}$ & 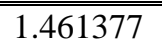 & $\begin{array}{l}0.1439 \\
\end{array}$ \\
\hline "Nifty (Y) & -1.645204 & $\begin{array}{l}0.0999 \\
\end{array}$ & $\overline{c 7.505718}$ & 20.0000 & -1.081258 & $\begin{array}{c}0.2796 \\
\end{array}$ & $\begin{array}{l}1.509697 \\
\end{array}$ & $\begin{array}{l}0.1311 \\
\end{array}$ \\
\hline 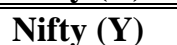 & -1.739472 & 0.0820 & 3.624009 & 0.0003 & -0.654029 & 0.5131 & 21.201090 & 0.2297 \\
\hline $\begin{array}{l}\text { Nifty (Y) } \\
\end{array}$ & -1.340518 & 0.1801 & 7.008412 & 0.0000 & -1.275972 & 0.2020 & $\begin{array}{l}1.583900 \\
\end{array}$ & 0.1132 \\
\hline
\end{tabular}

The indices (Sensex and Nifty) were grouped on the basis of existence of ARCH and GARCH effect before and after the Brexit referendum. The above table No. 4.3 shows the changes in the volatility around the Brexit referendum. The volatility analyse the quality of volatility, meaning that current day's volatility due to state-of-the-art information would affect tomorrow's volatility or not. The model was run by employing all the three methods namely Normal Gaussian distribution, Student $t$ distribution and GED with fix parameter. In this case the ARCH effect signifies the effect of any state-of-the-art information that has come to the stock market. Therefore, any change in ARCH effect hints the effect of Brexit referendum on the stock market. It is evident from the above table that there was a GARCH effect before the referendum (Normal Gaussian distribution, Student $t$ distribution and GED with fix parameter) and there was neither ARCH nor GARCH effect after the referendum for Sensex. Similarly in case of Nifty fifty there was a GARCH effect before the referendum (Normal Gaussian distribution, Student $t$ distribution and GED with fix parameter) and there was neither ARCH nor GARCH effect after the referendum.

\section{RESIDUAL DIAGNOSTICS}

To investigate the existence of autocorrelation in the residuals Q - statistic test was conducted. If there is no serial correlation in the residuals, the autocorrelations and partial autocorrelations at all lags should be almost zero, and all Q-statistics should be insignificant with hefty p-values meaning that if the variance equation is perfectly specified, all Q-statistics should not be statistically significant. 
TABLE No. 4.4

CORRELOGRAM OF STANDARDIZED RESIDUALS - Q-STATISTICS ((NORMAL GAUSSIAN DISTRIBUTION, STUDENT T DISTRIBUTION AND GED WITH FIX PARAMETERS) - PRE BREXIT

\begin{tabular}{|c|c|c|c|c|c|c|c|c|c|c|c|c|}
\hline & \multicolumn{6}{|c|}{ Sensex } & \multicolumn{6}{|c|}{ Nifty } \\
\hline & \multicolumn{2}{|c|}{ N Gaussian D } & \multicolumn{2}{|c|}{ t distribution } & \multicolumn{2}{|c|}{ GED } & \multicolumn{2}{|c|}{ N Gaussian D } & \multicolumn{2}{|c|}{ t distribution } & \multicolumn{2}{|c|}{ GED } \\
\hline & $\begin{array}{c}\text { Q- } \\
\text { Stat }\end{array}$ & 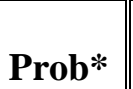 & & Prob* & & & $\begin{array}{l}\text { Q- } \\
\text { Stat }\end{array}$ & Prob* & $\begin{array}{c}\text { Q- } \\
\text { Stat }\end{array}$ & Prob* & $\begin{array}{c}\text { Q- } \\
\text { Stat }\end{array}$ & 1 \\
\hline 1 & 1.7589 & & 429 & 11 & & & 1.9197 & 0.166 & 2.1935 & 0.139 & 0.8475 & 80 \\
\hline 2 & 3.6023 & & 071 & & & & 3.3592 & & 624 & 86 & 777 & \\
\hline 3 & 4.8237 & & 5.0415 & & & & 4.5900 & 0.204 & 4.3592 & .225 & 8793 & .83 \\
\hline 4 & 5.9938 & & 5420 & & & & 5.4064 & & 922 & 320 & 0896 & \\
\hline 5 & 6.0246 & 94 & 5.7199 & 4 & 15 & & 5.4651 & 362 & 5.0165 & .414 & 1614 & 29 \\
\hline 6 & 7.5210 & 75 & 6.4719 & & & & 6.4514 & & 5.6359 & 0.465 & 6.2546 & \\
\hline 7 & 8.1440 & 20 & 7.1668 & & 5.9087 & & 7.6356 & 366 & 6.2214 & 0.514 & 7.5036 & .37 \\
\hline 8 & 8.2980 & 05 & 7.8491 & & 6.5209 & & 8.2092 & 0.413 & 6.9119 & 0.546 & 9.0145 & .34 \\
\hline 9 & 8.6874 & & 7.9344 & & & & 8.3362 & & 6.9944 & 0.638 & 9.6398 & \\
\hline 10 & 10.476 & 00 & .2749 & 6 & & & 9.5885 & 0.477 & 8.4837 & 0.582 & 11.697 & $\overline{\bar{C}}$ \\
\hline 11 & 10.533 & 83 & 9.3177 & & & & 9.6249 & 0.564 & 8.5088 & 0.667 & 13.600 & .25 \\
\hline 12 & 14.148 & $291 \mid$ & 11.813 & .461 & 11.502 & .4.4 & 11.970 & 0.448 & 11.578 & 0.480 & 17.356 & 0.13 \\
\hline
\end{tabular}

TABLE No. 4.5

CORRELOGRAM OF STANDARDIZED RESIDUALS - Q-STATISTICS ((NORMAL GAUSSIAN DISTRIBUTION, STUDENT T DISTRIBUTION AND GED WITH FIX PARAMETERS) - POST BREIXT

\begin{tabular}{|c|c|c|c|c|c|c|c|c|c|c|c|c|}
\hline & \multicolumn{6}{|c|}{ Sensex } & \multicolumn{6}{|c|}{ Nifty } \\
\hline & \multicolumn{2}{|c|}{ N Gaussian D } & \multicolumn{2}{|c|}{ t distribution } & \multicolumn{2}{|c|}{ GED } & \multicolumn{4}{|c|}{ N Gaussian D $t$ distribution } & \multicolumn{2}{|c|}{ GED } \\
\hline & $\begin{array}{c}\text { Q- } \\
\text { Stat }\end{array}$ & & & & & 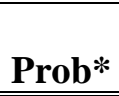 & $\begin{array}{c}\text { Q- } \\
\text { Stat }\end{array}$ & 1100 & $\begin{array}{c}\text { Q- } \\
\text { Stat }\end{array}$ & Prob* & $\begin{array}{l}\text { Q- } \\
\text { Stat }\end{array}$ & 100 \\
\hline 1 & 0.5330 & & & & & & 0.5775 & 0.447 & 0.8782 & 0.349 & 0.3824 & \\
\hline 2 & 816 & & & & & & 0.5814 & & & 44 & & \\
\hline 3 & $\underline{0}$ & & & & & & 0. & & & 26 & & \\
\hline$\overline{4}$ & 5.6057 & $31 \|$ & 91 & 28 & & & 6.3 & 0.177 & 6.3444 & 175 & 2.3945 & 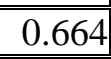 \\
\hline 5 & 5.7032 & & 5.7194 & $1,0.334$ & & & 6.3654 & & & & & .72 \\
\hline 6 & 802 & & & & & & & & & & & \\
\hline$\overline{7}$ & 7.1002 & 19 & 00 & 30 & & & 7.8332 & 348 & 590 & 373 & 3.5175 & .83 \\
\hline 8 & 7.9516 & & 8.1890 & & & & 9.2892 & & 9.1974 & 326 & 4.7627 & \\
\hline 9 & 8.3201 & & 954 & & & & 9.4112 & 0.400 & 9.6893 & 0.376 & 5.8628 & 0.75 \\
\hline 10 & 10.824 & & 10.769 & 76 & & & 11.701 & 0.306 & 11.647 & 0.309 & 5.8702 & .82 \\
\hline 11 & 744 & & & & & & & & 13.401 & 0.268 & 15.227 & \\
\hline 12 & 7.084 & 0.146 & 16.656 & .163 & 17.292 & 0.159 & 17.972 & $\mid 0.117$ & 17.112 & 0.145 & 15.470 & .2 \\
\hline
\end{tabular}

The test accepts the null hypothesis of no auto correlation in the time series data. The above correlogram of squared residuals test results indicate that the residuals are not auto correlated. 
TABLE No. 4.6

\section{NORMALITY TEST - JARQUE-BERA STATISTICS}
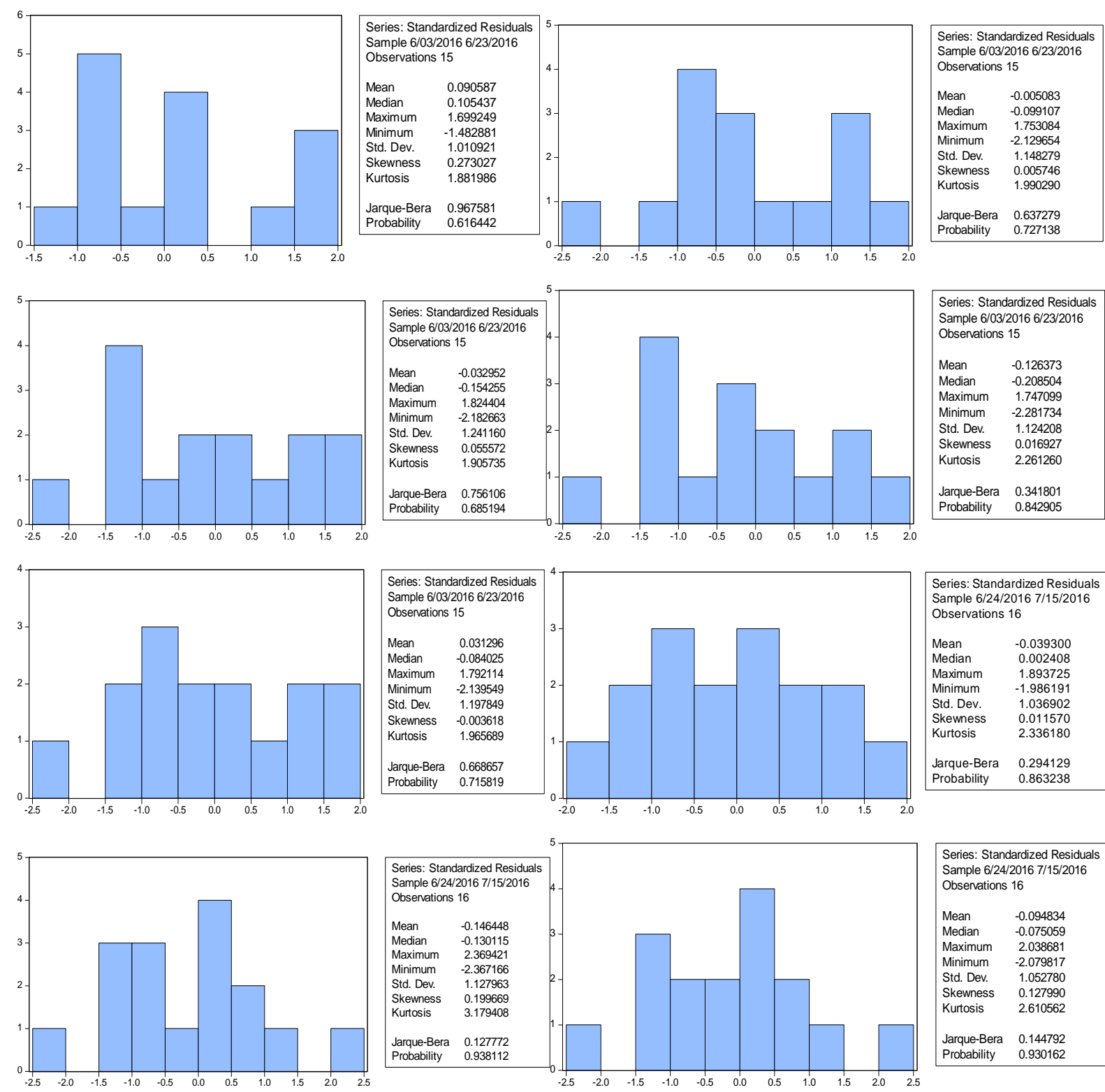

In order to investigate the normality of the data distribution Jarque-Bera test for normality has been conducted. It is evident from the above table that the residuals are normally distributed.

TABLE No. 4.8

\section{ARCH EFFECT TEST - (NORMAL GAUSSIAN DISTRIBUTION, STUDENT T DISTRIBUTION AND GED WITH FIX PARAMETERS)}

\begin{tabular}{|c|c|c|c|c|c|c|c|}
\hline \multicolumn{4}{|c|}{ Sensex } & \multicolumn{4}{|c|}{ Nifty } \\
\hline \multicolumn{2}{|c|}{ Pre Brexit } & \multicolumn{2}{|c|}{ Post Brexit } & \multicolumn{2}{|c|}{ Pre Brexit } & \multicolumn{2}{|c|}{ Post Brexit } \\
\hline $\begin{array}{l}\text { Obs*R- } \\
\text { squared }\end{array}$ & Prob. & $\begin{array}{l}\text { Obs*R- } \\
\text { squared }\end{array}$ & Prob. & $\begin{array}{l}\text { Obs*R- } \\
\text { squared }\end{array}$ & Prob. & $\begin{array}{l}\text { Obs*R- } \\
\text { squared }\end{array}$ & Prob. \\
\hline 0.310760 & 0.5772 & 0.139781 & 0.7085 & 0.288293 & 0.5913 & 0.004598 & 0.9459 \\
\hline 0.952225 & 0.3292 & 0.483299 & 0.4869 & 1.043591 & (0.3070 & 0.131025 & 0.7174 \\
\hline 0.963601 & 0.3263 & 0.077873 & 0.7802 & 0.710137 & 0.3994 & 0.383269 & 0.3879 \\
\hline
\end{tabular}


To investigate the presence of heteroscedasticity in the distribution of the residuals, an ARCH test was conducted for all the parameters (Normal Gaussian distribution, Student $t$ distribution and GED with fix parameters). The ARCH test results indicate that there are no ARCH effects in the collected distribution. In other words, there is no heteroscedasticity in the residuals; thus, the residuals can be said to be homoscedastic.

\section{DISCUSSION AND CONCLUSION}

The current study focussed on the impact of the British decision of voting to leave the European Union and its impact on Indian benchmark indices Sensex and Nifty fifty. In order to realise the stated objectives the researcher has collected the data from 24-06-2015 to 19-07-2016 from the capital line data base. The collected data has been tested for stationarity. An event study methodology has been employed to ascertain the abnormal returns (AR) and student t test has been used to test the significance. For the purpose of the study the dates on which the Brexit referendum came out were taken as the event date $(t=0)$. The thirty one days enclosing the referendum (i.e., $t=-15, \ldots \ldots, 0 \ldots \ldots$, $+15)$ is labelled as the event window. Further, to investigate the time varying volatility $\operatorname{GARCH}(1,1)$ model has been applied.

The current study revealed that in case of Sensex the highest AR recorded in the pre-event period ranging from the lowest value of -0.012869276 on day -5 to the highest value of 0.01440066 on day 6 . However, in the post-event period the highest AR recorded ranging from the lowest value of 0.012429592 on day 3 to the highest value of 0.019001654 on day 12 . On the event day i.e. Brexit results announcement day the abnormal returns were 0.025392241 with a $t$ value of 3.101151087 . However, none of the Abnormal Return (AR) were statistically significant at 5\% other than the event day (0) and on day 12. Therefore, we can conclude that Brexit referendum has an impact on Sensex on the event day. In case of Nifty fifty, the study pointed out that the highest AR recorded in the preevent period ranging from the lowest value of -0.013942608 on day - 5 to the highest value of 0.013206845 on day -6 . However, in the post-event period the highest AR recorded ranging from the lowest value of -0.013230584 on day 3 to the highest value of 0.017280312 on day 12 . On the event day i.e. Brexit results announcement day the abnormal returns were 0.023632173 with a t value of 2.763586544. Once again, none of the Abnormal Returns were statistically significant at conventional level of $5 \%$ other than on the event day (0) and on day twelfth with a $t$ value of 2.020789107. Therefore, we can conclude that Brexit referendum has an impact on Nifty Index on the day of event. To investigate the significant difference between the pre-event window abnormal returns ( -15 to -1$)$ and post event window abnormal returns (+15 to 1$)$ for 15 days event window and 7 days event window student $t$ test was run in both the cases we were unable to reject the null hypothesis, meaning that there was no significant difference between pre-event window abnormal returns and post event abnormal returns.

The historical volatility (standard deviation) and GARCH $(1,1)$ modelling techniques have been used to analyse the possible shift in volatility of the chosen indices (Sensex and Nifty fifty). The SD of pre Brexit event of Sensex was 0.00745234 and for post event was 0.008857243 in case of Sensex it has increased by 0.001404903 . However, in case of Nifty Fifty pre Brexit referendum the SD was 0.007389438 and post Breixt referendum it was 0.008517576 . The historical volatility in Nifty fifty increased by 0.001128138 . That the SD of pre Brexit event in case of Sensex for 7 days event window was 0.00992117 and for post event was 0.009024771 . Therefore in case of Sensex it has come down by -0.0008964 . For Nifty Fifty pre Brexit referendum the SD was 0.009731123 and post Breixt referendum it was 0.008872168 . The historical volatility of Nifty fifty was come down by 0.00085895 . However, the change in historical volatility in both the cases were not statistically significant. In the last phase the indices (Sensex and Nifty) were grouped on the basis of existence of ARCH and GARCH effect before and after the Brexit referendum. We found a GARCH effect before the referendum (Normal Gaussian distribution, Student t distribution and GED with fix parameter) and there was neither ARCH nor GARCH effect after the referendum for Sensex. Similarly in case of Nifty fifty there was a GARCH effect before the referendum and there was neither ARCH nor GARCH effect after the referendum. Our results seem to agree with the findings of Sathyanarayana 
and Pushpa (2016). Anti Brexiteers claim that the consequences of the Brexit referendum would be huge for the British because, the British economy and legal system have become strongly unified with the EU. Untangling those relationships is likely to be culturally and economically disturbing. On the other hand, Brexit supporters have argued that U.K. will be better off in the long run outside the European Union, with sovereignty and control over immigration, economic regulations and to get control of England's own borders. The 2008 financial crisis hit Eurozone very badly and the current Syrian refugee crisis have put the EU's broken political institutions under strain. Now the British exit could further disturb Europeans' confidence that the EU venture can endure over the long run, causing other countries to eye the exits. The outcome of the Brexit poll was a shock to the global economy. It creates a colossal gloom of uncertainty over financial markets across the globe particularly for higher risk class assets like stocks, forex etc. Stock markets may react temporarily and the magnitude is likely to be small especially from the perspective of Indian stock markets.

Though, the current study confirms the impact of Brexit referendum on both Sensex and Nifty fifty, they were however, statistically significant only for the event day and twelfth day. There was a volatility in both the chosen indices for the fifteen days event window. However, it was not statistically significant. The study confirmed the existence of GARCH effect before the event window $(-15$ to -1$)$ and later we found that there was no GARCH or ARCH effect. This signifies the strength of the Indian economy (may be coupled with decrease in crude oil prices). India doesn't have to fear much about the consequences of Brexit, but stock market and currency may turn volatile in the short run. India makes more investments in Britain than in the rest of the EU put together. Since Britain, provided a gateway to the EU for many Indian companies, now these companies are expected to relocate their operations to other European nations. The most affected sectors might be pharmaceuticals, IT, banking and automobile. Devaluation of Pound may affect the IT Company's revenue in the short run and would also make tough for the exporters as we have trade surplus with UK. Another worrying factor for Indian stock markets are the abrupt increase in global risk factor may affect the FIIs inflows. According to a country brief by the Ministry of External Affairs. Brexit could jeopardise those investments in the UK as it may hurt the operations and earnings of these companies.

\section{REFERENCES}

[1] Acemoglu, Daron, Simon Johnson, James Robinson, and Yungyong Thaicharoen (2003), "Institutional causes, macroeconomic symptoms: volitily, crises and growth", Journal of Monetary Economics, 50, 49-123.

[2] Aggarwal, R. (2003). "Exchange rates and stock prices: A study of the US capital markets under floating exchange rates". Akron Business and Economic Review, 12, 7-12.

[3] Alexander, S. (1961). "Price Movements in Speculative Markets: Trends or Random Walk," Industrial Management Review, Vol.2.7-26.

[4] Allvine FC, O'Neill DE (1980). "Stock market returns and the presidential election cycle/implications for market efficiency". Financial Analysts Journal.36:49-56.

[5] Anderson, H. D., Malone, C. B., \& Marshall, B. R. (2008). "Investment returns under rightand left-wing governments in Australasia". Pacific-Basin Finance Journal, 16(3), 252-267.

[6] Angboza, Lazarov A. and Ranga Narayanan (1996), "Catastrophic Shocks in the PropertyLiability Insurance Industry: Evidence on Regulatory and Contagion Effects", The Journal of Risk and Insurance, Vol. 63, No. 4, pp. 619-637.

[7] Asprem, M. (1989). "Stock prices, asset portfolios and macroeconomic variables in ten European countries". Journal of Banking and Finance, 13(4/5), 589-612.

[8] Babu, M. S., \& Prabheesh, K. (2007). "Causal Relationships between Foreign Institutional Investments and stock returns in India". International Journal of Trade and Global Markets, Vol. 1 No. 3, 259-265.

[9] Babu, S.Suresh and Venkateswarlu (2013). "Impact of Union Budget on Indian Stock Prices". International Journal of Management Research and Review, Volume 3, Issue 5 
[10] Beaulieu, M., Cosset, J., Essaddam, N., (2005), “The impact of political risk on the volatility of stock returns: The case of Canada", Journal of International business studies, 36, 701-718.

[11] Bernanke BS, Kuttner KN (2005). "What Explains the Stock Market's Reaction to Federal Reserve Policy?" Journal of Finance. 60(3):1221-1257

[12] Beyer SB, Jensen GR, Johnson RR (2008). "The presidential term". Journal of Portfolio Management. 135-142

[13] Bialkowski, J., Gottschalk, K., \& Wisniewski, T. P. (2008). "Stock Market Volatility around National Elections". Journal of Banking \& Finance, 32(9), 1941-1953.

[14] Bittlingmayer G., (1992). "Stock returns, real activity and the trust question", Journal of Finance, 47(5), 1701-30.

[15]Cartaer, D. and Simkins, B. (2004). "The market's reaction to unexpected, catastrophic events: the case of airline stock returns and the September 11 the attacks". The Quarterly Review of Economics and Finance, 44, pp. 539-558

[16] Charest, G. (1978). "Dividend Information, Stock Returns and Market Efficiency-II". Journal of Financial Economics, Vol.12. 297-330.

[17] Chen, S.S., Chen H.C., 2007. "Oil prices and real exchange rates". Energy Economics 29 (3), 390-404.

[18] Chopra, N., J. Lakonishok, \& J. Ritter. (1992). "Measuring Abnormal Performance: Do Stock Overreact?” Journal of Financial Economics, Vol.31. 235-268.

[19] Ciner C. (2001). "Energy Shocks and Financial Markets: Nonlinear Linkages". Studies in Non- Linear Dynamics and Econometrics. 5, 203-212.

[20] Cook, T. and T. Hahn. (1989) "The Effect of Changes in the Federal Funds Rate Target on Market Interest Rates in the 1970s," Journal of Monetary Economics, 24(3), 331-51.

[21] Coudert, V., Mignon, V., Penot, A., (2008). "Oil price and dollar”. Energy Studies Review 15 (2), 48-65

[22] Cutler M. D., Poterba J. M., and Summers L. H., (1989). "What moves stock prices?” Journal of Portfolio Management, 15(3). 4-12.

[23] Diamonte R., Liew. J., Stevens, R., 1996, "Political risk in emerging and developed markets", Financial Analysts Journal, 52 (3), 71-76.

[24] Dimitrova, D. (2005), "The Relationship between Exchange Rates and Stock Prices - Studied in Multivariate Model", Issues in Political Economy, vol.14.

[25] Divya Verma Gakhar, Neha Kushwaha and Vinita Ashok (2015). "Impact of Union Budget on Indian Stock Market". Scholedge International Journal of Management \& Development. Vol.02, Issue 1. 21-36.

[26] Dolley, James C. (1933). "Characteristics and Procedure of Common Stock Split-Ups", Harvard Business Review, Volume 37, Issue 5. 316-326.

[27]Doong, S.-Ch., Yang, Sh.-Y., Wang, A., 2005. "The dynamic relationship and pricing of stocks and exchange rates: Empirical evidence from Asian emerging markets," Journal of American Academy of Business. Vol.7, No. 1. 118-23.

[28] Dopke, J and Pierdzioch, C. (2006). "Politics and the stock market: Evidence from Germany", European Journal of Political Economy, Vol. 22, No. 4. 925-943.

[29] Drazen A (2001). "The political business cycle after 25 years", NBER macroeconomics annual 2000. Cambridge MA: MIT Press, 15, pp. 75-117

[30] Elton, E., Gruber, M., Das, S., and Hlavka, M. (1993). "Efficiency with Costly Information: A Reinterpretation of Evidence from Managed Portfolios," The Review of Financial Studies, Vol.6. 1-22.

[31]Erb C., Harvey. C, Viskanta T., (1996). "Political risk, economic risk and financial risk", Financial Analysts Journal, Nov-Dec 1996.

[32] Evelita E. Celis and Leow Jia Shen (2015). "Political Cycle and Stock Market - The Case of Malaysia", Journal of Emerging Issues in Economics, Finance and Banking (JEIEFB). Vol. 4 Issue 1

[33] Fama EF (1970). "Efficient capital markets: a review of theory and empirical work". Journal of Finance. 25: 383-417. 
[34] Fama, E. F. (1965). "The behaviour of stock-market prices", The Journal of Business, Vol. 38, No. 1. 34-105.

[35] Fama, F. (1981). "Stock Returns, Real Activity, Inflation, and Money". American Economic Review. 71: 545-565.

[36]Fleming, M.J. and E.M. Remolona. (1999) "Price Formation and Liquidity in the U.S. Treasury Market: The Response to Public Information," Journal of Finance, 54(5), 1901-15.

[37] Gartner M (1994) "The quest for political cycles in OCED economies". European Journal of Political Economics. 10. 427-440

[38] Gartner M, Wellershoff KW (1995). "Is there an election cycle in American stock returns?" International Rev Econ Finance. 4(4). 387-410

[39] Goodell, J. W., \& Vähämaa, S. (2013). "U.S. Presidential elections and implied volatility: The role of political uncertainty". "Journal of Banking \& Finance, 37. 1108-1117.

[40] Hamilton, J. D. 2003. What is an Oil Shock?” Journal of Econometrics, 113. 363-98.

[41] Hamilton, J.D. (2008) "Assessing Monetary Policy Effects Using Daily Federal Funds Futures Contracts," Federal Reserve Bank of St. Louis Review, 90(4). 377-93.

[42] Hamilton, James D., Herrera, M. Ana (2004), "Oil Shocks and Aggregate Macroeconomic Behaviour: The Role of Monetary Policy", Journal of Money, Credit \& Banking Vol. 36, No.2. 265

[43] Hensel, C. R., \& Ziemba, W. T. (1995). "United States investment returns during Democratic and Republican administrations, 1928-1993". Financial Analysts Journal. 61-69.

[44] Hibbs, Jr. D. A (1977), "Political parties and macroeconomic policy", The American Political Science Review, Vol. 71, No. 4. 1467-1487.

[45] Huang, R. D. (1985). "Common stock returns and presidential elections". Financial Analysts Journal, (March/April):58-61.

[46] Javid, A. Y. (2007). "Stock market reaction to catastrophic shock: Evidence from listed Pakistani firms". PIDE Working Papers, 37.

[47] Jensen, M. C. and Benington, G. A. (1970) "Random walks and technical theories: Some additional evidence", Journal of Finance, Vol. 25, No. 2. 469-482.

[48] Johnson, R. R., Chittenden, W. T., \& Jensen, G. R. (1999). "Presidential politics, stocks, bonds, bills, and inflation”. The Journal of Portfolio Management, 26. 27-31.

[49] Joseph, N. (2002). Modelling the impacts of interest rate and exchange rate changes on UK Stock Returns. Derivatives Use, Trading \& Regulation, 7(4), 306-323

[50] Kaur, Harvinder (2004). "Stock Market Volatility in India. The Indian Journal of Commerce", Volume 57, 4, 55-70.

[51] Kavussanos, M.G. and S.N. Marcoulis, (1997). "The stock market perception of industry risk and microeconomic factors: The case of the US water transportation industry versus other transport industries". Transportation Research. Part E, Logistics and Transportation Review 33: $147-158$.

[52] Khakan Najaf, Rabia Najaf, Amir Iqbal, Imran Hussain Shah (2015). "The Impact of Terrorism and Political Events on Stock Market: Empirical Evidence from Pakistan". International Journal of scientific research and management (IJSRM). Volume 3 issue 6 June 2015. 3036-3045

[53] Khalid, Ahmed M. and Rajaguru, Gulasekaran (2010). "The impact of political events on financial market volatility: Evidence using a Markov Switching process". Globalisation and Development Centre. Paper 43. http://epublications.bond.edu.au/gdc/43

[54] Kilian, L. (2008). "Exogenous Oil Supply Shocks: How Big Are They and How Much Do They Matter for the US Economy?" Review of Economics and Statistics 90, 216-40.

[55] Kim, Harold Y. and Jianping Mei (1999), "Political risk and stock returns: the case of Hong Kong", Stanford University Working Paper Series, September.

[56] Kim, k.-h. (2003). "Dollar exchange rate and stock price: Evidence from multivariate cointegration and error correction model". Review of Financial Economics. 301-313. 
[57] Kim, S.-J., Nguyen, D.Q.T. (2008). "The reaction of the Australian financial markets to the interest rate news from the Reserve Bank of Australia and the U.S. Fed". Research in International Business and Finance 22, 378-395.

[58] Kithinji and Ngugi (2013). "Stock market performance before and after election: NSE Case study"

[59] Kongprajya, A. (2010), "An analysis of the impact of political news on Thai stock market".A Dissertation presented in part consideration for the degree of "MA Risk Management". University of Nottingham.

[60] Kothari S, Warner J. Econometrics of event studies (2006). "In: Espen Eckbo B, editor. Handbook of corporate finance: empirical corporate finance". Elsevier/North.

[61] Kutchu, Vishal (2012). "Testing Semi-Strong Efficiency of Indian Stock Market - A Study on Effect of Union Budget 2012 on Six Select Sectorial Stocks". International Refereed Research Journal, Volume III, 3(2), 74.

[62] Li J, Born JA (2006). "Presidential election uncertainty and common stock return in the United States". Journal of Finance Research. 29(4):609-622

[63] Lin, C.T. \& Wang, Y.H. (2003), "The Impact of Political Uncertainty on the Stock Market: Evidence from Taiwan". Student Dissertation.

[64] Liu. (2007). "An Empirical Study of the Presidential Elections Effect on Stock Market in Taiwan, South Korea, Singapore, Philippine, and Indonesia". MA Finance and Investment, the University of Nottingham.

[65] Ma, Y., Sun, H.-L., \& Tang, A. P. (2003). "The return and volume effects of political-risk event on foreign joint ventures: Evidence from the Tiananmen Square crisis". Global Financial Journal, 49- 64.

[66] MacKinlay C. (1997). "Event studies in economics and finance". Journal of Economic Literature; 35(1):13-39.

[67] MacRae, C. D. (1977). "A political model of the business cycle", Journal of Political Economy, Vol. 85, No. 2. 239-263.

[68] Malkiel, B. (1995). "Returns from Investing in Equity Mutual Funds 1971 to 1991,"Journal of Finance, Vol. 50, Issue 2. 549-572.

[69] Maloney, Michael T. and J. Harold Mulherin (2003), "The Complexity of Price Discovery in an Efficient Market: The Stock Market Reaction to the Challenger Crash", Journal of Corporate Finance, Vol. 9, Issue 4, pp. 453-479.

[70] Manning, N., (1991). "The UK oil industry: Some inferences from the efficient market hypothesis". Scottish Journal of Political Economy 38: 324-334.

[71] Mei, J. \& Guo, L. (2002), "Partisan Politics and Stock Market Performance: The Effect of Expected Government Partisanship on Stock Returns in the 2002 German Federal Election". Working paper

[72] Mukhopadhyay, D. and Sarkar, N. (2003). "Stock Return and Macroeconomic Fundamentals in Model - Specification Framework: Evidence from Indian Stock Market. Indian Statistical Institute, Economic Research Unit”. Discussion Paper. 1-28

[73] Myers, John and Bakay, Archie (1948) "Influence of Stock Split-Ups on Market Price," Harvard Business Review, Vol. 26. 251-55.

[74] Nguyen, A.P., Enomoto,C., (2009). "Acts of Terrorism and Their Impacts on Stock Index Returns and Volatility: The Cases of the Karachi and Tehran Stock Exchanges". International Business \& Economics Research Journal - Volume 8, Number 12.

[75] Nicholas Chen (2004). "Effect of the U.S. Presidential Election on Stock Market Performance", NUS Student investment society.

[76] Niederhoffer V., (1971). "The analysis of world events and stock prices", Journal of Business, 44(2), 193-219.

[77] Niederhoffer, V., Gibbs, S., \& Bullock, J. (1970). "Presidential elections and the stock market". Financial Analysts Journal, 26, 111-113. 
[78] Nordhaus, W. D. (1975). "The political business cycle", The Review of Economic Studies, Vol. 42, No. 2.169-190.

[79] Ortega, D. F., \& Tornero, Á. P. (2009). "Politics and Elections at the Spanish Stock Exchange". Paper presented at the 9th Global Conference on Business \& Economics, Cambridge University, UK.

[80] Pantzalis, C. Stangeland, D. A. and Turtle, H. J. (2000). "Political elections and the resolution of uncertainty: The international evidence", Journal of Banking \& Finance, Vol. 24, No. 10. 1575-1604.

[81] Peel, D. \& Pope, P. (1983). "General Election in the U.K. in the Post-1950 Period and the Behaviour of the Stock Market", Investment Analysis 67, 4-10.

[82] Person, J. (2012). "Mastering the Stock Market: High Probability Market Timing and Stock Selection Tools". New Jersey: John Wiley \& Sons.

[83] Rafaqet Ali and Muhammad Afzal (2012). "Impact of global financial crisis on stock markets: Evidence from Pakistan and India". Journal of Business Management and Economics Vol. 3(7). 275-282.

[84] Rigobon, R., and B.P. Sack. (2004) "The Impact of Monetary Policy on Asset Prices," Journal of Monetary Economics, 51, 1553-75.

[85] Robin Jonsson and Jessica Radeschnig (2014). "From Market E ciency To Event Study Methodology: An Event Study of Earnings Surprises on Nasdaq OMX Stockholm", Bachelor Thesis in Economics submitted to Division of Business and Social Sciences. Malardalen University Sweden.

[86] Sabnavis (2005). "How sensitive is the Stock Market". Business Standard, August 22.

[87] Sadorsky, P. (1999), "Oil price shocks and stock market activity", Energy Economics, No. 2. 449469.

[88] Santa-Clara P, Valkanov R (2003). "The presidential puzzle: political cycles and the stock market”. Journal of Finance. LVIII (5):1841-1872

[89] Sathyanarayana, Pushpa B. V. (2016). "Global stock markets reaction to special events: evidence from Brexit referendum". International Journal of Business and Administration research review. Vol. 1, Issue No. 4.

[90] Schwert G. W., (1989), "Why does stock volatility change over time?" Journal of Finance, 44 (5), 1115-53.

[91] Seppi, D. (1992). "Block Trading and Information Revelation around Quarterly Earnings Announcements," Review of Financial Studies, Vol. 5. 281-306.

[92] Shelor, R. M., Anderson, D. C., and Cross, M. L. (1990). "The impact of California earthquake on real estate firms stock value". The Journal of Real Estate Research, 5 (3), 335 340.

[93] Singh, Anoop (2006), "Macroeconomic volatility: The policy lessons from Latin America", IMF Working Paper WP/06/166, International Monetary Fund, Washington, D.C. July.

[94] Stovall RH (1992). "Forecasting stock market performance via the presidential cycle". Financial Analysts Journal 48(3), 5-8.

[95] Sturm, R. R. (2013). "Economic policy and the presidential election cycle in stock returns", Journal of Economics and Finance April 2013, Volume 37, Issue 2. 200-215

[96] Suleman, M.T. (2012), "Stock Market Reaction to Terrorist Attacks: Empirical Evidence from a Front Line State". Australasian Accounting Business and Finance Journal. Volume 6 Issue 1.

[97] Thomas, Susan, and Shah, Ajay (2002). "Stock Market Response to Union Budget". Economic and Political Weekly, February, 455-458

[98] Tzachi Zach (2003). "Political Events and the Stock Market: Evidence from Israel", International journal of business, 8(3).

[99] Vuchelen, J. (2003). Electoral systems and the effects of political events on the stock market: The Belgian case. Economics \& Politics, 15(1), 85-102.

[100] Zach, T. (2003). "Political Events and the Stock Market: Evidence from Israel". International Journal of Business, 8(3). 
[101] Zhao X, Liano K, Hardin WG III (2004). "Presidential election cycles and the turnof-the-month effect". Social Science Q 85(4):958-973

[102] Zuwena Zainabu (2014). "An assessment of the effect of general elections on the stock market returns in Kenya", a research project submitted to the University of Nairobi. 